\title{
PENGARUH PROPOLIS TERHADAP KOLAGENISASIPADA PROSES PENYEMBUHAN LUKA SUBKUTAN PUNGGUNG MENCIT YANG DIINDUKSI BAKTERI ACTINOBACILLUS ACTINOMYCETEMCOMITANS
}

\author{
Asdar \\ Bagian Periodonsia \\ Fakultas Kedokteran Gigi Universitas Hasanuddin
}

\begin{abstract}
Propolis, the resinous hive product by bees, is important in the defence of the hive. It is know that extract of propolis exhibits such pharmacological activities as antimicrobia, antiviral, antifungal, anti-inflamatory, immunostimulatory and promote wound healing. The objective of this study was to investigate the influence of the propolis on the formation of collagen in the wound healing process of the subcutan injury of mice that were induced with Actinobacillus actinomyctemcomitans (A.actinomyctemcomitans)

This study applied 24 female BALB/c mice of 2 - 3 months of age with the weight of 20 -30 grams. On the first day the whole population were injected with
\end{abstract} A.actinomyctemcomitans subcutanly. The second day mice were randomly devided into two groups that was the group with special treatment and the controlled ones. The group under treatment were given the extract of propolis 100 $\mathrm{mg} / \mathrm{kg}$ body weight every day. While the controlled ones were only given aquades.

Histological observation was conducted upon each group on the third, seventh and fourteenth days after $A$. actinomyctemcomitans injection. There-suits of the observation was based on the density collagen fiber. The data obtained then analyzed by using Mann-Whitney $U$ test. The results of the present study indicated that the administration of $100 \mathrm{mg} / \mathrm{kg}$ BWpropolis peroral may stimulate collagen synthesis.

Keywords: Propolis,

Actinobacillus actinomyctemcomitans, Collagen fiber 
PENDAHULUAN

Penyakit

periodontal

disebabkan oleh akumulasi bakteri plak dan produknya pada permukaan gigi dan subgingiva.

Diantara lebih 300 spesies bakteri yang ditemukan dalam rongga mulut manusia, diperkirakan hanya 10 - 20 spesies yang berperan dalam patogenesis penyakit periodontal destruktif. Salah satu bakteri yang diketahui dominan pada penyakit periodontal destruktif adalah Actinobacillusactinomycetemcomita ns (A.actino-mycetemcomitans). ${ }^{1}{ }^{2}$ Bakteri ini dikenal sebagai penyebab sejumlah infeksi pada rongga mulut, .terutama penyakit periodontal yang destruktif pada orang dewasa. Disamping itu bakteri ini juga diketahui dapat menyebabkan infeksi ekstra oral diantaranya endocarditis, abses otak, pneumonia, osteomyeleitis dan infeksi pada saluran kencing. ${ }^{3}$ 45 Pada percobaan yang dilakukan pada mencit, ditemukan bahwa bakteri ini dapat menimbulkan abses subkutan. ${ }^{6}$

Kemampuan
A.actinomyceterncomitans sebagai agen etiologi penyakit periodontal des-truktif disebabkan bakteri tersebut memiliki sejumlah determinan virulensi yaitu : "pacteriocin, leukotoksin, kolagenase, endotoksin, fibroblast inhibitory factor, bone resorption inducing factor, menginduksi produksi sitokin dari makrofag, memodifikasi fungsi netftrofil, dan secara in vitro mendegradasi imunogltfbulin yang menginvasi selsel epithel. Selain itu juga terjadi respon pada pejamu berupa peningkatan antibodi dalam serum atau saliva pada pasien LJP. ${ }^{7}$

Kolagen adalah protein berbentuk serat yang tersebar luas dalam tubuh dan merupakan bagian utama jaringan ikat padat sehingga kolagen merupakan protein fibrosa terbanyak dalam tubuh $(30 \%$ dari total protein). Kolagen merupakan komponen utama kartilago dan tulang, tendo, ligamen, otot, kulit dan struktur lainnya. ${ }^{9,10}$ Sel yang berperan dalam proses pembentukan kolagen adalah fibroblas. Penghambatan 
pertumbuhan atau perusakan
fibroblas akan diekspresikan
sebagai penurunan sintesis kolagen
dan selanjutnya akan termanifestasi
dalam beberapa bentuk penyakit
peruiodontal maupun penyakit
lainnya.

Walaupun telah diterima secara urflum bahwa antibiotik tidak diperlukan dalam perawatan rutin periodontitis, tetapi dengan seringrvya terjadi kegagalan pada perawatan secara mekanis, maka pemberian antibiotik sebagai terapi tambahan perawatan penyakit periodontal secara mekanis dapat menj adi pertimbangan."

Dewasa ini terdapat usaha merflanfaatkanbahan-bahan alami dalam pelayanan kesehatan, Propolis merupakan salah satu produk alami yang dihasilkan oleh lebah madu yang digunakan sebagai perekat untuk memelihara sarangnya. $^{12}$ Sejumlah penelitian menunjukkan bahwa propolis mempunyai efek antimikroba terhadap bakteri (gram positif dan gram negatif), anti jamur dan anti viral. 13-15 Efek lain dari propolis adalah kemampuannya untuk menstimulasi sistim imun, serta memacu pembentukan sel danjaringan.

Pada penelitian ini, pembuatan luka pada mencit dilakukan dengan menginjeksi secara subkutan punggung mencit dengan bakteri A.actinomycetemcomitans sehingga akan terjadi abses subkutan. ${ }^{6}$

\section{BAHAN DAN CARA}

\section{Pembuatan Ekstrak Propolis}

Propolis yang digunakan adalah propolis dari jenis lebah Trigona sp., yang berasal dari Sulawesi Selatan. Proses ekstraksi propolis dilakukan di laboratorium PPOT-UGM. Teknik ekstraksi yang digunakan adalah teknik Reflux. Setelah dilakukan ekstraksi, etanol diuapkan sehingga diperoleh ekstrak kering. Propolis tersebut kemudian diencerkan dengan akuades untuk mendapatkan konsentrasi $2 \mathrm{mg} / \mathrm{ml}$. Dosis yang digunakan dalam penelitian ini adalah dosis tunggal sebesar 100 $\mathrm{mg} / \mathrm{kg}$ BB atau 0,1 mg/g BB. 
2. Preparasi

Bakteri

\section{A.actinomyceterncomitans}

Pembiakan bakteri. Bakteri

A.actinomycetemcomitans diperoleh dari laboratorium Mikrobiologi

Fakultas Kedokteran Hewan -

UGM. Bakteri tersebut dikultur dalam Tood- Hewitt Broth (Oxoid). Media pembiakan bakteri dibuat dengan cara: $30 \mathrm{~g}$ ToodHewitt Broth dimasukkan dalam 1 liter akuades, disuplemen dengan $1 \%(w t / v)$ yeast extract kemudian disterilkandalam autoklaf $\left(121^{\circ} \mathrm{C}\right.$ selama 15 menit). Suasanaanaerob diperoleh dengan memasukkan dalamsunkup anaerob. Kemudian sunkup anaerob dimasukkan dalam inkubator (pada suhu $37^{\circ} \mathrm{C}$ dengan 5\% $\mathrm{CO}_{2}$ ). Bakteri dipanen setelah 6 hari. Perhitungan jumlah sel bakteri A.actinomycetemcomitans. Untuk menimbulkan abses subkutan pada punggung mencit digunakan bakteri A.actinomycetemcomitans dengan jumlah sel $1 \times 10^{1118}$ Perhitungan jumlah sel dilakukan menggunakan haemositometer dengan cara : suspensi bakteri yang telah diencerkan sebanyak $10 \mathrm{ml}$ dituang dalam tabling eppendorf dan ditambah $90 \mathrm{ml}$ tripan biru. Sepuluh mikroliter suspensi hasil pengecatan ini lalu dituang ke chamber haemositometer, kemudian diamati dibawah mikroskop cahaya dengan pembesaran $400 \mathrm{X}$. Total jumlah sel bakteri dari setiap $1 \mathrm{ml}$ suspensi bakteri ditentukan dengan menggunakan formulasi : Sel per ml $=A \times 10 \times 10^{4}(A=$ jumlah bakteri dalam 5 kotak). Suspensi bakteri dibuat dalam jumlah 1 X 10" bakteri/ IOOmIPBSsteril.

\section{Pelaksanaan Penelitian}

Dalam penelitian ini digunakan mencit $B A L B / c$ betina umur 8-10 minggu dengan berat badan 20 - $30 \mathrm{~g}$. Dua puluh empat ekor mencit yang telah dipilih sesuai dengan kriteria dibagi dalam 2 kelompok yang sama besar yang dibagi secara acak. Kedua kelompok diinjeksi bakteri A.actinomycetemcomitans pada hari pertama.

Mulai pada hari kedua kelompok perlakuan diberi ekstrak 
propolis peroral dengan dosis 100 $\mathrm{mg} / \mathrm{kg} / \mathrm{BB} / \mathrm{hari}$, sedang kelompok kontrol diberi plasebo dengan dosis dan cara yang sama dengan kelompok perlakuan.

Cara pembuatan luka/abses pada punseuns mencit. Alat suntik $1 \mathrm{ml}$ diisi suspensi bakteri A.actinomycetemcomitans yang berisi 1 x 10" bakteri. Mencit disiapkan pada alat fiksasi (trap) yang selanjutnya disuntik secara subkutan pada daerah punggung.

Cara pemberian obat peroral.

Pemberian ekstrak propolis dan plasebo dilakukan sehari setelah injeksi A.actinomycetemcomitans pada kelompok perlakuan dan kontrol. Pemberian obat dilakukan dengan alat suntik yang telah dimodifikasi ujung jarumnya diberi bulatan kecil dengan diameter 2 $\mathrm{mm}$ atau kanula.Kanula tersebut dimasukkan ke mulut mencit tersebut. Kemudian secara perlahan-lahan kanula dimasukkan sampai ujungnya mencapai lambung (intragastric), lalu alat suntik ditekan secara perlahan agar obatnya masuk ke lambung mencit
(100 mg/kg/BB/hari).

Pensukuran diameter luka/abses. Cara pengukuran dilakukan dengan menggunakan jangka sorong. Diukur diameter terpanjang dan terpendek dari abses, kemudian dihitung nilai reratanya.

Pembuatan dan pengecatan sediaan histologic Pemeriksaan histologis dilakukan pada hari ke-3, ke-7 dan ke-14 pada kedua kelompok. Proses pembuatan sediaan dan pengecatan serabut kolagen dilakukan dengan metode Mallory. ${ }^{19}$ Pemilihan sediaan. Bagian yang menjadi target pengirisan adalah titik pusat luka atau bekas luka yang telah ditandai sebelumnya. Setiap blokjaringan diiris menjadi 15 irisan.Arah pemotongan dari permukaan ruar kulit ke dalam (vertikal). Dari 15 irisan diambil 5 irisan secara acak untuk diwamai. Dari 5 irisan/preparat diambil 1 sampel secara acak, sehingga didapatkan 4 sampel dari tiap kelompok. Pengamatan dan pengumpulan data. Pengamatan serabut kolagen 
dilakukan di bawah mikroskop cahaya. Kriteria penilaian histologis dibuat berdasarkan kepadatan serabut kolagen yang dibuat dengan modifikasi kriteria pada penelitian Soesilowati-Handogo. ${ }^{20}$ Penilaian dilakukan berdasarkan kriteria sebagai berikut:

(+) : Serabut kolagen terlihat sangat tipissedikit?

$(++)$ : Serabut kolagen terlihat menyebar tipis sedikit

$(+++)$ : Serabut kolagen terlihat sedang

$(++++)$ : Serabut kolagen terlihat padat/tebal

Hasil yang diperoleh diubah dalam bentuk skor sebagai berikut:

(+) skor $=1 ;(++)$ skor $=$ $2 ;(+++)$ skor $=3 ;(++++)$ skor $=4 \%$.

Data yang diperoleh selanjutnya dianalisis secara statistik menggunakan metode statstistik Mann-Whitney $U$ test dengan taraf signifikansi $95 \%$.

\section{HASIL PENELITIAN}

Rangkuman hasil pengujian statistik menggunakan uji MannWhitney untuk mengetahui kebermaknaan pengaruh propolis terhadap kepadatan serabut kolagen antara kelompok perlakuan dan kelompok kontrol ditunjukkan pada label 1.

Tabel 1. Hasil uji Mann-Whitney pengaruhpropolis terhadap kepadatan serabut kolagen dan antara kelompok kontrol (A) dan kelompokperlakuan (B)

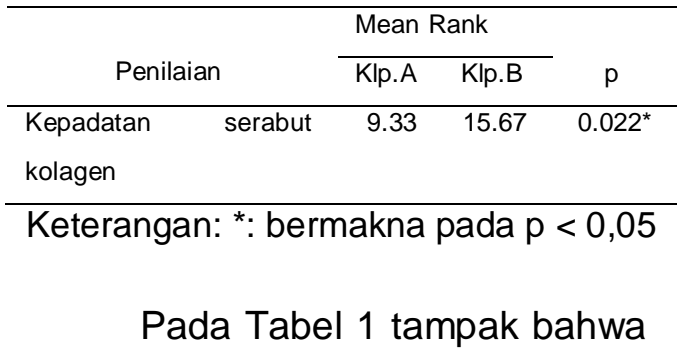
kepadatan serabut kolagen kelompok perlakuan menunjukkan perbedaan yang bermakna dibanding kelompok kontrol $(p<0,05)$.

Untuk mengamati lebih lanjut pengaruh lama waktu pemberian propolis terhadap kepadatan serabut kolagen antara kelompok perlakuan dan kontrol dapat dilihat pada Tabel 2.

Tabel 2. Hasil uji MannWhitney perbedaan kepadatan serabut kolagen antara kelompok kontrol(A) dan kelompok perlakuan 
(B) pada hari-hari pengamatan:

\begin{tabular}{|c|c|c|c|c|}
\hline \multirow{2}{*}{$\begin{array}{r}\text { Hari } \\
\text { ke }\end{array}$} & \multicolumn{3}{|c|}{ Mean Rank } & \multirow[b]{2}{*}{$P^{\prime}$} \\
\hline & Kip. & $A$ & KIp.B & \\
\hline $3-$ & 4,00 & & 5,00 & 0,495 \\
\hline 7 & 3,00 & & 6,00 & $0,046^{*}$ \\
\hline 14 & 2,75 & & 6,26 & 0,036 * \\
\hline
\end{tabular}

Keterangan:*bermakna pada $p \leq 0.05$

Hasil analisis statistik pada

Tabel 2 tampak bahwa pada hari ke-3, selisih diameter abses awalakhir menunjukkan perbedaan yang bermakna antara kelompok perlakuan dan kontrol $(p<0,05)$, sedangkan kepadatan serabut kolagen antara kelompok perlakuan dan kontrol tidak berbeda bermakna $(p>0,05)$, sedang pada hari ke-7 dan ke-14, kepadatan serabut kolagen menunjukkan perbedaan yang bermakna antara kelompok perlakuan dan kontrol $(p<0,05)$.

Bedasarkan pengamatan histologis, tampak bahwa pada hari ke-3 serabut kolagen sudah terbentuk pada kedua kelompok, walaupun kepadatannya masih terlihat sangat tipis, dan tidak tampak perbedaan kepadatannya serabut kolagen antara kelompok perlakuan dengan kelompok kontrol.Selanjutnya pada hari ke-7, menunjukkan kepadatan serabut kolagen yang semakin tinggi.Hasil pengamatan ini didukung analisis statistik pada tabel 2.Gambaran serabut kolagen daef ah luka subkutan punggung mencit kelompok perlakuan dan kontrol pada hari ke-7 ditunjukkan pada Gambar 1.

Pada pengamatan histologis pada hari ke-14, tampak bahwa serabut kolagen pada kedua kelompok semakin padat.Data analisis statistik pada Tabel 2 juga menunjukkan bahwa kepadatan serabut kolagen pada kelompok perlakuan lebih tinggi dari kelompok kontrol.

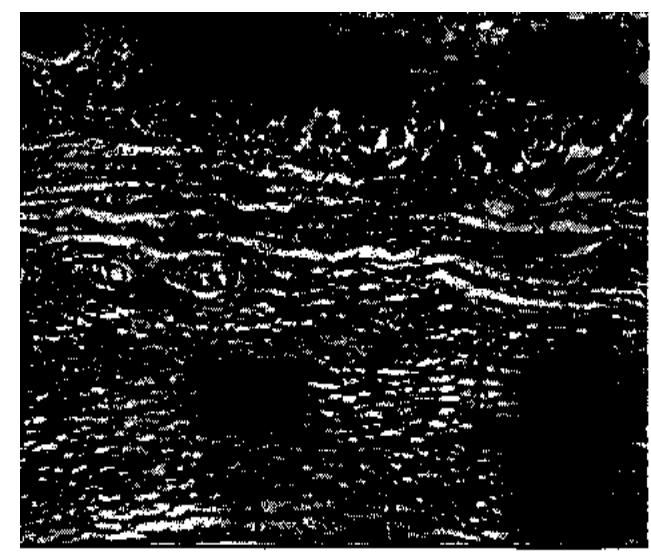

Gambar 1A.Gambaran serabut kolagen daerah subkutan punggung mencit pada hari ke-7. pada kelompok perlakuan. Serabut kolagen tampak berwarna biru. Pengecatan Mallory. Pembesaran $100 \mathrm{X}$. 


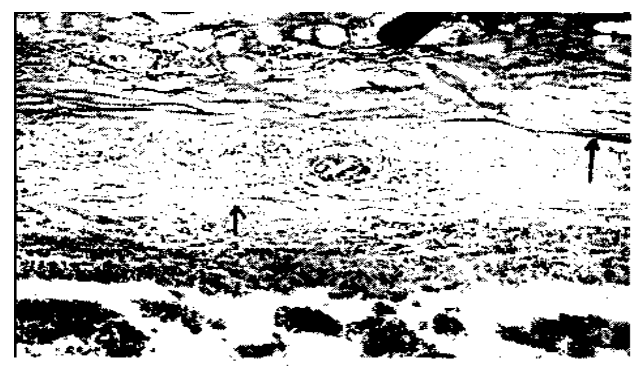

Gambar IB. Gambaran serabut kolagen daerah subkutan punggung mencit pada hari ke-7. pada kelompok kontrol. Serabut kolagen tampak berwarna biru. Pengecatan Mallory. Pembesaran $100 \mathrm{X}$.

\section{PEMBAHASAN}

Hasil penelitian menunjukkan bahwa kepadatan serabut kolagen pada kelompok perlakuan yang diberi propolis dengan dosis 100 $\mathrm{mg} / \mathrm{kg}$ BB berbeda bermakna dibanding kelompok kontrol.Ini dapat diartikan bahwa kolagenisasi luka mencit yang diinduksi bakteri A.actinomycetemcomitans pada kelompok perlakuan lebih cepat dibanding kelompok kontrol. Menurut Kaal, ${ }^{17}$ Scheller $\mathrm{dkk}^{21}$ dan Ghizalberti $^{22}$ salah satu karasteristik propolis adalah mempunyai kemampuan menstimulasi pembentukan sel dan jaringan. Karasteristik ini penting dalam mempercepatpenyembuhan luka.
Walaupun dalamstudi literatur tidak disebutkari peran propolis secara langsung terhadap fibroblas, dapat diduga bahwa propolis berpengaruh secara tidak langsung terhadap fibroblas, yaitu antara lain melalui perantaraan makrofag. Dari penelitian Scheller $\mathrm{dkk}^{21}$ disebutkan bahwa propolis mempunyai sifat imunogenitas dengan cara mengaktifasi makrofag. Dapat diduga makrofag inilah yang selanjutnya menstimulasi fibroblas untuk memproduksi serabut kolagen.Pendapat tersebut didukung Tatefuji dkk yang menyatakan bahwa propolis mempunyai efek meningkatkan penyebaran dan mobilitas makrofag murine. Menurut Fawcett ${ }^{24}$ dan Hefti $^{25}$ makrofag antara lain memproduksi Interleukin 1 (TL-1), fibroblast growth factor (FGF) dan tumor necroting factor (TNF). Fibroblast growth factor diketahui mempunyaikemampuan menginduksi proliferasi fibroblas mencit, sedanglL-I mempunyai fungsi antara lain memediasi remodeling, reparasi dan inflamasi 
jaringan melalui proses fisiologis dan patologis. Interleukin 1 dan TNF dapat memacu proliferasi fibroblas. Keduanya bersifat kemotaksis terhadap fibroblas dan selanjutnya menstimulasi sintesis kolagen. ${ }^{26}$

Pada hari ke-3, walaupun didapatkan bahwa dari data kasar tampak kepadatan serabut kolagen kelompok perlakuan lebih tinggi dari kelompok kontrol, namun hasil analisis statistik tidak berbeda bermakna.Hal ini mungkin disebabkan karena pada hari ke-3 virulensi bakteri

A.actinomycetemcomitans masih tinggi yang ditandai dengan diameter abses pada kedua kelompok belum menurun.Dengan demikian aktivitas toksin bakteri masih lebih dominan dibanding zat aktif propolis. Menurut Mitchell dan Cotran $^{26}$ dan Spector dan Spector ${ }^{27}$ penyebab paling lazim dalam gangguan proses kolagenisasi adalah inflamasi aktif yang terus menerusdisebabkan oleh infeksi bakteri. Diketahui bahwa bakteri A.actiiiomycetemcomitans memiliki sejumlah determinan virulensi yang kompleks, yaitu antara lain: leukotoksin, kolagenase, fibroblast inhibitory factor (FIF). ${ }^{7,8}$ Leukotoksin A.actino-mycetemcdmitans memperlihatkan spesifisitas sitolitik dengan merusak lekosit polimorfonuklear (PMN) dan makrofag. ${ }^{8}$ Menurut Socransky dan Haffajee, ${ }^{28}$ leukotoksin

A.actinomycetemcomitans tidak hanya mem-pengaruhi PMN dan monosit/makrofag, tapi juga membunuh limfosit $B$ dan $T$, atau niemfasilitasi penekanan sel-sel imun. Bakteri ini juga memproduksi protein yang dapat mengaktivasi penekan sel T. Selain itu adanya determinan virulensi kolagenase pada bakteri A.actinomycetemcomitansakan menyebabkan degradasi kolagen yang sudah terbentuk dalam jaringan, yang semakin diperparah oleh adanya FIF yang menghambat sintesis kolagen. Penghambatan pertumbuhanfibroblas diekspresikan dengan penurunan sintesis kolagen.Dalam keadaan normal juga diketahui bahwa serabut kolagen terbentuk pada sekitar hari 
ke-5. ${ }^{29}$ Dengan demikian dapat difahami mengapa pada hari ke-3 penampakan serabut kolagen pada kelompok perlakuan dan kontrol masih sangat sedikit.

Hasil analisis statistik pada hari ke-7 dan 14 menunjukkan bahwa kepadatan serabut kolagen pada kelompok perlakuan berbeda bermakna dengan kelompok kontrol. Ini berarti bahwa pada hari ke-7 dan 14 serabut kolagen pada kelompok perlakuan menunjukkan kepadatan yang lebih tinggi dibanding dengan kelompok kontrol.

Analisis decara deskriptif pada Tabel 3 menunjukkan bahwa sampai pada hari ke-3 tidak ada dari kedua kelompok yang menunjukkan penyembuhan luka abses. Selanjutnya pada kelompok hari ke7, satu dari kelompok perlakuan menunjukkan penyembuhan, sedangkan pada kelompok kontrol tidak ada.Pada kelompok hari ke14, tiga dari kelompok perlakuan menunjukkan penyembuhan, sedangkan pada kelompok kontrol tetap tidak ada. Dari data ini dapat diduga bahwa ekstrak propolis mempunyai potensi antimikroba secara in vivo terhadap bakteri A.actinomycetemcomitans. Menurut Kaal, ${ }^{17}$ Root $^{30}$ kandungan asam ferulat dari propolis diketahui mempunyai efek antimikroba terhadap bakteri gram positif dan gram negatif. Dengan efek antimikroba tersebut maka jumlah maupun virulensi bakteri A.actinomycetemcomitans akan menurun, yang selanjutnya menfasilitasi terjadinya proses kolagenisasi dengan baik. Komponen cinnamic dan flavonoid dari propolis dilaporkanjuga dapat menghambat motilitas bakteri. ${ }^{15}$ Untuk membuk-tikan daya antimikroba propolis terhadap bakteri A.actinomycetemcomitans diperlukan penelitian lebih lanjut. Sementara itu, pada kelompok perlakuan yang belum mengalami penyembuhan maupun kelompok kontrol, proses sintesis serabut kolagen juga tetap berlangsung, sebagaimana hasil yang ditunjukkan di bawah pengamatan mikroskop serta dalam uji statistik yang dapat dilihat pada Tabel 2. Dari fakta 
tersebut dapat diajukan bahwa walaupun masih terdapat aktivitas bakteri A.actinomycetemcomitans pada daerah luka namun tidak menghentikan proses sintesis kolagen oleh fibroblas. Hal ini mungkin disebabkan karena pada hari k-7 dan 14, virulensi bakteri A.actinomycetemcomitans sudah mulai menurun. Penelitian yang dilakukan oleh Saglie $\mathrm{dkk}^{31}$ menunjukkan bahwa konsentrasi yang rendah lipopolisakarida (LPS) dari

bakteri

\section{A.actinomycetemcomitans}

menstimulasi makrofag yang selanjutnya mempengaruhi IL-1 a, IL-1 b dan tumor necroting factor (TNF). Hal ini didukung oleh Takemura dkk (1998) cit. Susilowati $^{32}$ yang menyatakan bahwapengamh LPS pada proliferasi sel tergantung pada konsentrasi stimulasi.Pengamh LPS bersifat bifasik, berarti pada konsentrsi rendah LPS mampu mening-katkan proliferasi sel, sebaliknya pada konsentrasi yang lebih tinggi.Seperti yang telah disebutkan EL-1 dan TNF dapat menstimulasi fibroblas mensintesis kolagen. Walaupun proses kolagenisasi terjadi pada kedua kelompok, hasil analisis statistik menunjukkan bahwa kepadatan serabut kolagen pada kelompok perlakuan lebih tinggi dari pada kelompok kontrol. Kondisi ini disamping berkaitan dengan efek antimikroba dari ekstrak propolis yang diberikan secara sistemik pada kelompok perlakuan, juga mungkin disebabkan oleh karasteristik propolis yang dapat menstimulasi sistim imun. Aktivitas imunologis dari propolis diduga berkaitan dengan aktivasi makrofag yang meningkatkan kapasitas fagositnya dan juga pengaruhnya terhadap faktor-faktor regulasi sel $B$ dan sel $T^{21}$

\section{KESIMPULAN}

Dari hasil penelitian ini dapat disimpulkan bahwa pemberian propolis peroral dengan dosis 100 $\mathrm{mg} / \mathrm{kg}$ BB dapat memacu kolagenisasi luka subkutan punggung mencit yang diinduksi bakteri Actinobacillus 
actinomycetemcomitans.

\section{SARAN}

Diperlukan penelitian lebih lanjut mengenai pengaruh propolis terhadap aktivitas sel makrofag dan fibroblas secara langsung.

\section{DAFTAR PUSTAKA}

1. Carranza, F.A., (ed), 1984, Glickman's Clinical

Periodontology, Ed. Ke-6, W.B. Saunders Company,

Philadelphia, Him. 361-90.

2. Socransky,S.S.andHaffajee,A.D, 1994, Evidence of bacterial etiology: a historical perspective, Periodontol. 2000,5:7-25.

3. Brooks, G.F., Butel, J.S. and Ornstan, L.N., 1991, Jawetz, Melnick and Adelberg's medical microbiology, Ed. ke-19, Appleton \& Lange, California, Him. 227.

4. Kaplan, A.H., Weber, D.J., Oddone, E.Z. and Perfect, J>R., 1989, Infection due to Actinobacillus actinomycetemcomitans: $\quad 15$ cases and review,
Rev.Infect.Dis.11:46-63.

5. Picket, M.J., Hollis, D.G., and Bottone, E.J., 1991, Miscellanous Gram negative Bacteria. Dalam Manual of Clinical Microbiology, IA.Balows, editor, Ed. ke-5, American Society for Microbiology, Washington D-C, Him. 420.

6. Chen, P.B., Davern, L.B., Neiders, M.E., Reynolds, H.M. and Zambon, J.J., 1991, Analysis on in vitro lymphoproliferative responses and antibody formation following subcutaneus injection of Actinobacillus actinomycetemcomitans and Wolinella recta in a murine model, Oral Microbiol. Immunol., 6:12-16.

7. Haffajee, A.D. and Socransky, S.S., 1994, Microbial etiological agents of destructive periodontal deseases, Periodontol. 2000, 5: 78-111.

8. Fives-Taylor, P.M, Meyer, D. and Mintz, K., 1996, Virulence factors of the periodontopathogen Actinobacillus 
actinomycetemcomitans, J. Periodontol., 67: 291 - 7.

9. Junqueira, L.C. and Carneiro, J. and Kelley, R.O., 1995, Basic Histology, Ed. ke-8, Appleton and Lange, Stamford, Him. 88117.

10. Bergman, R.A., Afifi, A.K., Heidger, P.M., 1996, Histology,W.B. Saunders Co., Phila

delphia, Him. 42-53.

11. Madinier,I.M., $\quad$ Fosse,T.B., Hitzig,C, Charbit,Y. and Hannoun,L.R., 1999, Resistence profile survey of periodontal strain of Actinobacillus actionmycetemcomitans, J.Periodontol.,70:888-

12. Hill, R., 1981, Propolis the natural antibiotic, Ed. ke-6, Thorsons Publisher Ltd, Wellingborough.

13. Ikeno,K., Ikeno,T., and Miyazawa,C, 1991 ,Effect of Propolis on Dental Caries inRats, Caries Res.,25: 347 351.

14. Kunjungiev, A., Tsvetkova,L, Serkedjieva, Y, Bankova.,
Christov, R. and Popov, S., 1999, Antibacterial, antifungal and antiviral activity of propolis of different geographic origin, J. Ethnopharmacol., 64(3): 235-40. 15. Mirzoeva,O.K., Grishanm,R.N., and Calder,P.C, 1997, Antimicrobial Action of Propolis and Some of Components: the Effect on Growth Membrane Potential and Motility of same of Bacteria, Microbial Res.,152:239-46.

16. Chen, Y., 1993, Apiculture in China, pp: 96-8, Agricultural Publishing House.

17. Kaal, J., 1991, Natural Medicine from Honey Bees (Apitherapy), Kaal's Printing House, Amsterdam, Him. 8-21.

18.18. Herminajeng, E., 2001, Respon Imun Protektif Terhadap Protein Permukaan Actinobacillus actinomyte mecomitans Pada Mencit, Tesis, Universitas Gadjah Mada, Yogyakarta.

19. The Histology Staff, 1966, Laboratory Syllabus Cell and Tissue Structure, University 
of California, School of Medicine, San Fransisco, California, Him. 59-66.

20.Soesilowati-Handogo, A.S.K., 1988, Gambaran mikroskopik ligamentum periodontale tikus (Rartus norvegikus) post-natal setelah radiasi dengan sinar gamma in utero, Tesis, Universitas Gadjah Mada, Yogyakarta.

21. Scheller, S., Gazda, G., Pietsz, G., Gabrys, J.,

22.Szumlas, J., Eckert, L. and Shani, J., 1988, The ability of ethanol extract of propolis to stimulate plaque formation in immunized mouse spleen cells, Pharmacol.

Res.

Commuh.,20(4): 323 -

23.Ghisalberti, EX., 1979, Propolis:

A Review, Annual Report of the International Bee Research Association, Western Australia, Him.59-84.

24.Tatefuji, T, Izumi, N., Ohta, T., Arai, S., Ikeda, M. and Kurimoto, M., 1996, Isolation and Identification of Compounds from Brazilian Propolis Which
Enhance

Macrophage

Spreading and Mobility,

Biol.Pharm.Bull., 19(7): 966-70.

25. Fawcett, D.W., 1994, A Textbook of Histology,Ed. ke-12, Chapman \& Hall, New York, Him. 133-168.

26. Hefti, A.F., 1993, Aspects of Cell Biology of the Normal Periodontium, Periodontol. 2000,3:64-75.

27. Mitchell, R.N and Cotran, R.S., 1997, Acute and Chronic Inflammation, dalam V. Kumar, R.S.Cotran and S.L.Robbins: Basic Pathology, 6 th ed., W.B. Saunders Co., Philadelphia.

28. Spector, W.G and Spector, T.D., 1989, An Introduction to General Pathology, Ed. ke-3, terj. oleh: Soetjipto, Haryoso, A. Hana and P. Astuti, GMU Press, Yogyakarta, Him. 71-165.

29. Socransky, S.S. and Haffajee, A.D., $\quad$ 1991, Microbial mechanisms in the pathogenesis of destructive periodontal deseases; a critical assesment, J. Periodont. Res., 26: 195212. 
30.Saptoyono, B., 1995, Pengaruh aplikasi lokal getah pisang pada penyembuhan luka pasca pencabutan gigi marmot, Tesis, Universitas Gadjah Mada, Yogyakarta.

31. Root, A.I., 1983, The ABC and XYZ of bee culture, The A.I. Root Company., Ohio, Him. 539-41.

32. Saglie, F.R., Simon, K., Merrill, J. and Koeffler, H.P., 1990, Lipopolysaccharide from Actinobacillus actinomycetemcomitans

stimulates macrophages to produce interleukin-1 and tumor necrosis factor mRNA and protein, Oral Microbiol. Immunol., 5: 256 - 62.

33. Susilowati, H., 2001, Pengaruh Stimulasi Lipopolisakarida Bakteri Gram Negatif Terhadap Pasasi-0 dan 1 Sel Fibroblas Ligamen Periodontal dan Gingiva Tikus, Tesis, Universitas Gadjah Mada, Yogyakarta. 